\title{
ATTACHMENT AND FAMILY FUNCTIONING AGAINST LONELINESS
}

\author{
Rahayu Diah*, Puspitasari Meiliyanti, Safitri Jihan, Alkatiri Zakki Abdallah \\ Department of Psychology, Mulawarman University, Indonesia \\ *E-mail: diah.rahayu@fisip.unmul.ac.id
}

\begin{abstract}
This study aims to determine family attachment and functioning on loneliness in adolescents with working mothers. This study uses a quantitative approach. The subjects were 106 adolescents with mothers working in Samarinda selected using the technique. Sampling purposive data collection methods used were the loneliness scale, the scale of attachment, and the family functioning scale. The collected data were analyzed with the help of the Statistical Package for Social Science (SPSS) 21.0 for the windows program. The results showed stickiness and functioning of the family have a significant influence on the value of $F$ Count equal to 40184 and $p$ of 0000 and has an $R^{2}$ of 0.438 .
\end{abstract}

\section{KEY WORDS}

Attachment, family functioning, loneliness.

The increased rights of women and the increasing acceptance of career women made many women decide to be in a career even when they have to carry out their obligations as mothers because they meet family needs or engage in a particular profession according to their wishes.

Meanwhile, in Samarinda, it was recorded that in 2019 there were 403,214 women from the age range of 15 years and over, including women who were married and had children with working status either as laborers, entrepreneurs, or casual workers (Central Statistics Agency of Samarinda City, 2019). Based on the results of research by Nilakusmawati and Susilawati (2012), from several factors that cause a married woman to work, it is found that the wife's last education level and the total amount of husband's income are the factors that cause a woman with a married status to decide to work.

A child has the right to receive affection from his family, including the mother, and vice versa, for a mother to spend time with her child is, of course, an obligation. However, it is different when some women with the status of mothers have to spend most of their time fulfilling their obligations as career women. The amount of time that must be passed for mother and child to build an attachment to one another, of course, can lead to feelings of loneliness in children. The functioning of the family may not be fulfilled because the role of the mother is divided, namely, as a mother and career woman.

A survey on the condition of loneliness in England conducted by the Mental Health Foundation in 2010 found that 24 percent of 2256 research subjects felt lonely, with the highest level of loneliness experienced by subjects aged 18-34 years (Mental Health Foundation, 2010). Based on the results of existing studies, it can be concluded that adolescents can experience feelings of loneliness.

Sagan and Miller (2017) reveal that adolescents who experience loneliness tend to feel hopeless, bored with impatience, self-humiliation, and depression. This occurs because adolescents do not have a support system in their lives. Meanwhile, according to Sagan and Miller (2017), the factors that influence loneliness are feelings of inferiority complex, personal perfectionism, shame, social anxiety, hopelessness, isolation, isolation, attachment, and family functioning.

Teens who experience loneliness spend much time alone because adolescents who experience loneliness do not have lost their attached figure. Not only that but family functioning in adolescents is also stated to affect loneliness in adolescents. Based on parents' absence, children do not have an attached figure in their life. Children will find it easier to feel isolated and lonely. 
According to Cendra (2012), ineffective communication in the family can result in loneliness in family members, including children. This happens because children do not get the space to express them and channel their emotions so that children begin to feel that no one cares about them, which then results in feelings of loneliness in children. According to Saputri, Rahman, and Kurniadewi (2012), loneliness is described as subjective anxiety when a social relationship loses its essential characteristics.

Tarabulsy and Symons (2016); namely, attachment is a relationship that develops because of the interaction between children and parents, contributing to bonds and influencing each other. In children who have a comparable figure, especially mothers, children will build trust between individuals and their environment, especially their families, to communicate in the family and reduce the risk of loneliness in children. Children can avoid feelings of isolation that cause negative emotions, anger, and attachment experiences to their parents.

According to Adnyani and Supriyadi (2020) family, the function is a characteristic that exists in a family, and a family can meet all the needs of family members. There is a sense of love and togetherness that can encourage each family member to grow into himself. The feeling of loneliness experienced by adolescents with working mothers is due to adolescents who do not fully feel the role of the mother as an attached figure. In addition, family functioning in adolescents is also not fulfilled due to the lack of the role of mothers in the household.

There are several objectives to be achieved in this study, namely to determine the effect of attachment on loneliness in adolescents with working mothers in Samarinda and to determine the effect of family functioning on loneliness in adolescents with working mothers in Samarinda. This study is expected to provide thoughts about family attachment and loneliness in adolescents with working mothers.

\section{METHODS OF RESEARCH}

The type of research used in this research is quantitative research. Quantitative research itself, according to Arikunto (2010), is research that in the process and the results uses many numbers both from the data collection process and how researchers translate the results of the data they get. The research design used in this study is divided into two, namely descriptive and inferential statistics. The descriptive statistical research design aims to provide an overview of data distribution on attachment and family functioning towards loneliness in adolescents with working mothers in Samarinda. Meanwhile, inferential statistics aims to determine whether there is an effect of family attachment and functioning on loneliness in adolescents with working mothers in Samarinda.

Research subjects in this study were adolescents with working mothers in Samarinda. Meanwhile, there are 106 samples used by using simple random sampling with the criteria of adolescents with an age range of 15-20 years with working mothers who live in Samarinda. The data collection method used in this study is a measurement tool or instrument. There are three research instruments used, namely the scale of attachment, family functioning, and loneliness. This study uses a Likert-type scale. The Likert scale is used to measure people's attitudes, opinions, and perceptions about social phenomena (Sugiyono, 2012). Data analysis for research data processing uses multiple regression analysis to determine how much influence and predictive ability of the two independent variables on the dependent variable. All data analysis techniques were performed with the help of the SPSS (computer program statistical Packages for Social Science) version 21.0 for Windows.

\section{RESULTS OF STUDY}

Individuals who are the subjects of this study are adolescents with working mothers in Samarinda. The number of samples used as research was 106 adolescents. The characteristics of research subjects in adolescents with working mothers in Samarinda can be seen in the following table: 
Table 1 - Characteristics of Subjects by Age

\begin{tabular}{llll}
\hline No & Age & Amount & Percentage \\
\hline 1 & 15 years & 1 & $0.9 \%$ \\
2 & 16 years & 0 & $0 \%$ \\
3 & 17 years & 3 & $2.8 \%$ \\
4 & 18 years & 6 & $5.7 \%$ \\
5 & 19 years & 28 & $26.4 \%$ \\
6 & 20 years & 68 & $64.2 \%$ \\
Total & & 106 & $100 \%$ \\
\hline
\end{tabular}

Based on table 1 below, it can be seen that the members of the research subject who are 15 years old are one member $(0.9 \%)$, no member of the research subject is 16 years old $(0 \%), 17$ years old totaled three members $(2.8 \%), 18$ years old totaled $6(5.7 \%), 19$ years old totaled 28 members (26.4\%), and 20 years old totaled 68 members $(64.2 \%)$. So it can be concluded that the research subjects in adolescents with working mothers in Samarinda were dominated by members aged 20 years, amounting to 68 members or 64.2 percent.

Table 2 - Subject characteristics based on gender

\begin{tabular}{llll}
\hline No & Gender & Total & Percentage \\
\hline 1 & Male & 28 & $26.4 \%$ \\
2 & Female & 78 & $73.6 \%$ \\
Total & & 106 & $100 \%$ \\
\hline
\end{tabular}

Based on the two tables above, it can be seen that the members of the research subject who are male are 28 members (21.3\%), and those who are female are 78 members $(73.6 \%)$. So it can be concluded that the research subjects of adolescents with working mothers in Samarinda were dominated by female members, amounting to 78 members or 73.6 percent.

The hypothesis in this study is to determine the effect of family attachment and functioning on loneliness in adolescents with working mothers in Samarinda. The analysis technique used is multiple linear regression analysis. Based on the results of the full regression model test on the variables of attachment and family functioning towards loneliness together, the following results were obtained:

Table 3 - Hypothesis Test Results of Regression Analysis of the entire model

\begin{tabular}{|c|c|c|c|c|}
\hline Variable & F count & $\mathrm{F}$ table & R2 & $\mathrm{P}$ \\
\hline Loneliness (Y) & & & & \\
\hline $\begin{array}{l}\text { Attachment (X1) } \\
\text { Family Functioning (X2) }\end{array}$ & 40.184 & 3.090 & 0.438 & 0.000 \\
\hline
\end{tabular}

Based on table 3 , the results show $F$ count> $F$ table, which means that family attachment and functioning to loneliness have a significant effect with the value of $F=40.184, R 2=0.438$, and $p=0.000$. The contribution of the influence (R2) of family attachment and functioning to loneliness is 0.438 . This shows that 43.8 percent of the variation in loneliness can be explained by family attachment and functioning. At the same time, the remaining 56.2 percent is explained by other variables or other causes not examined in this study. This means that the significant hypothesis in this study is accepted. Then from the results of the regression analysis in stages, it can be seen as follows:

Table 4 - Results of Hypothesis Testing Staged Regression Analysis Model

\begin{tabular}{lllll}
\hline Variable & Beta & $\mathrm{t}$ & $\mathrm{t}$ Table & $\mathrm{P}$ \\
\hline Stickiness (X1) & -0648 & -8454 & 1983 & 0000 \\
Loneliness (Y) & -0048 & -0629 & 1983 & 0531 \\
$\begin{array}{l}\text { Family functioning (X2) } \\
\text { Loneliness (Y) }\end{array}$ & & & \\
\hline
\end{tabular}


Based on table 4, it can be seen that $t$ count> $t$ table, which means that there is a significant influence between attachment to loneliness with the value of beta $=-0.648, t$ count $=-8.454$, and $p=0.000(p<0.05)$.

Then the functioning of the family on loneliness, it shows $t$ count $<t$ table, which means that there is no significant effect with the beta value $=0.048$, t count $=0.629$, and $p=0.531$ $(p>0.05)$.

\section{DISCUSSION OF RESULTS}

This study aims to determine the effect of family attachment and functioning on loneliness in adolescents with working mothers in Samarinda with an age range of 15-20 years. The respondents' characteristics were dominated by the female gender, namely 73.6 percent or as many as 78 members of 106 respondents. Meanwhile, male respondents were 26.4 percent or 28 members out of a total of 106 respondents.

Based on table 26, the regression analysis test results show that $F$ count> $F$ table with $F$ count 40.184 and $F$ table 3.090 and $p$ of 0.000 . This means that the significant hypothesis in this study is accepted, which means that family attachment and functioning have a significant effect. The contribution of the influence (R2) of family attachment and functioning to loneliness is 0.438 . This shows that 43.8 percent of the variation in loneliness can be explained by family attachment and functioning. At the same time, the remaining 56.2 percent is explained through other variables not examined in this study.

This is in line with the research results conducted by Riza (2016), which states that the magnitude of maternal attachment, father attachment, and peer attachment to loneliness is 32.4 percent. This study shows that the higher the level of adolescent attachment to both mothers and fathers, or peers, the level of loneliness will decrease. Lack of interaction and communication between parents as comparable figures, especially mothers, increases the level of loneliness of adolescents.

Based on Khaeruddin and Ridfah's (2020) research, comparing high and low attachment levels in adolescents with working mothers in Makassar shows that more adolescents experience low attachment to their mothers. One possibility of low attachment is because their mother has a role other than the mother, namely the worker. Meanwhile, in Khaeruddin and Ridfah's research (2020), the highest level of attachment was in medium attachment with 59 members with a total of 85 members.

Hidayati (2016) argues that emotional loneliness occurs because of negative emotions due to dissatisfaction with intimate relationships. The intimate relationship here means the relationship between the teenager and his parents. This is based on the absence of an essential role for parents in the child's life not to have an attached figure in their life. Children will find it easier to feel isolated and lonely.

Hidayati's (2018) research results state a negative relationship between family functioning and loneliness, as evidenced by statistical calculations with a significance value (p) of 0.038 . This means that the better the family-owned family-owned by adolescents, the smaller it is for these adolescents to experience loneliness, and vice versa when adolescents have low-income family functioning, the higher the loneliness in adolescents.

According to DeGenova (in Hidayati, 2018), weak interactions between family members can result in loneliness in these family members. This happens because children do not get the space to express them and channel their emotions so that children begin to feel that no one cares about them, which then results in feelings of loneliness in children.

Working mothers can influence adolescents psychologically because they rarely meet child attachment figures. Children will feel lost, feel ignored and even feel alienated. Children will be more closed, shy, not confident, and can cause stress on children. Secure or fulfilled attachment in the first years of life will provide an essential foundation for later psychological development in the child's life (Aryanti, 2015). When the child's psychological needs are met, the child's risk of experiencing loneliness will decrease and vice versa; if the child's psychological needs are not met, the child's risk of experiencing loneliness will be even higher. By Nurjannah's (2018) statement, adolescents need parental attention in the form 
of love and affection to grow well from a psychological side. The form of parental love and affection is essential in building a good psychological state of children; therefore, if the child does not obtain the psychological needs in the form of love and attention from parents, the child is vulnerable to feeling lonely.

The family function is defined as how the family can carry out its functions effectively or ineffectively on the physical and emotional health of family members (Nisa \& Sari, 2020). Meanwhile, one of the factors that affect the functioning of the family is disorganization in the family, where family members fail to carry out their duties and obligations according to their respective status and roles (Mikolajczak, 2018). In this case, understanding the role and status of each as a family member is not easy. The failure to understand the role of adolescents, especially their mothers, causes adolescents not to feel the impact of the role of members in their family.

In adolescents with working mothers, children get used to the activities of the working mother and leave her for several hours without a mother figure. So the child can conclude that the role of the mother is not free from the work that the mother currently has so that the functioning of the family does not affect loneliness in adolescents. However, other factors influence loneliness, namely the unfulfilled emotional and social needs of adolescents (Dafnaz \& Effendy, 2020). Meanwhile, the emotional needs of adolescents can be obtained through a close relationship with their mother's figure. Based on the discussion of the research results described above, it can be concluded that attachment influences loneliness, while family functioning does not affect loneliness. There are still some deficiencies in this study; let us say that the number of respondents is only 106 respondents, and the research time is short.

\section{CONCLUSION}

Based on the research that has been done, it can be concluded that the proposed hypothesis is accepted, meaning that there is a significant influence between family attachment and functioning on loneliness in adolescents with working mothers in Samarinda. Then there is a negative and significant influence between attachments to loneliness in adolescents with working mothers in Samarinda. Then there is no influence between family functioning on loneliness in adolescents with working mothers in Samarinda.

Seeing that there is a significant influence between family attachment and functioning on loneliness in adolescents with working mothers in Samarinda, it is hoped that parents, especially mothers, are more able to play a role and be responsible as a mother and meet the needs of adolescents who are very important at their age to avoid feelings loneliness in adolescents. The researcher is fully aware that several discussions are not good enough in their delivery because of the limited subject and time.

So it is hoped that the following researchers interested in researching loneliness, attachment, and family functioning, especially in adolescents, are expected to examine more broadly the factors that can affect loneliness in adolescents. Both the variables of loneliness, attachment, and family functioning are expected to be better researched to get more satisfying results from the research done. It is hoped that the results obtained will be more profound and include a more comprehensive range of respondents to be more helpful for future researchers.

\section{REFERENCES}

1. Adnyani, N. N. T., \& Supriyadi, S. (2020). Peran Keberfungsian Keluarga, Subjective Well-being and Karakteristik Perilaku Minum Minuman Keras Terhadap Perilaku Minum Minuman Keras pada Remaja Laki-laki di Kabupaten Karangasem, Bali. Jurnal Psikologi Udayana, 168-177.

2. Arikunto, S. (2010). Prosedur penelitian: suatu pendekatan praktik (Edisi revisi). Jakarta: Bumi Aksara. 
3. Arikunto, S. (2013). Prosedur Penelitian: Suatu Pendekatan Praktik. Jakarta: Rineka Cipata.

4. Aryanti, Z. (2017). Kelekatan dalam Perkembangan Anak. Tarbawiyah Jurnal Ilmiah Pendidikan, 12(02), 245-254.

5. Akbag, M., \& Imamoglu, S. E. (2010). The prediction of gender and attachment styles on shame, guilt, and loneliness. Educational science: theory and practice, 10(2), 669-682.

6. Badan Pusat Statistik Kota Samarinda. (2020). Jumlah Penduduk Berumur 15 Tahun Ke Atas yang Bekerja Selama Seminggu yang Lalu Menurut Status Pekerjaan Utama and Jenis Kelamin di Kota Samarinda, 2015-2019. Diakses dari https://samarindakota.bps.go.id.

7. Cendra, A., (2012). Hubungan antara keberfungsian keluarga and kesepian pada remaja indonesia. Skripsi Sarjana Psikologi. Fakultas Psikologi Universitas Indonesia.

8. Dafnaz, H. K., \& Effendy, E. (2020). Hubungan Kesepian dengan Masalah Psikologis and Gejala Gangguan Somatis pada Remaja. Scripta Score Scientific Medical Journal, 2(1), 6-13.

9. Hidayati, D.S. (2016). Shyness and loneliness. Proceeding seminar ASEAN 2nd. Malang: Program Pasca Sarjana Psikologi Universitas Muhammadiyah Malang.

10. Hidayati, D. S. (2018). Family function and loneliness pada remaja dengan Orangtua Tunggal. Jurnal Ilmiah Psikologi Terapan, 6(1), 54-62.

11. Khaeruddin, K. N., \& Ridfah, A. (2020). Kelekatan Remaja dengan lbu yang Bekerja. Jurnal Psikologi Talenta, 3(1), 9.

12. Mikolajczak, M, Raes, M. E., Avalosse, H, \& Roskam, I. (2018). Exhausted Parents: Sociodemographic, Child-Related, Parent-Related, Parenting and Family-Functioning Correlates of Parental Burnout. Journal of Child and Family Studies, 27(2), 602-614.

13. Mental Health Foundation. (2010). The lonely society? Inggris: Mental Health Foundation.

14. Nurjannah, B. A. H. (2018). Kebutuhan Cinta and Kasih Sayang pada Remaja Peminum Alkohol. Fakultas Psikologi Universitas Ahmad DahlanYogyakarta.

15. Nisa, H, \& Sari, M. Y. (2020). Peran Keberfungsian Keluarga Terhadap Penerimaan Diri Remaja. Psikoislamedia: Jurnal Psikologi, 4(1), 13-25.

16. Nilakusmawati, D. P. E., \& Susilawati, M. (2012). Studi faktor-faktor yang mempengaruhi wanita bekerja di kota Denpasar. Jurnal Kependudukan and Pengembangan Sumber Daya Manusia, 8(1), 26-31.

17. Saputri, N. S., Rahman, A. A., \& Kurniadewi, E. (2012). Hubungan antara Kesepian dengan Konsep Diri Mahasiswa Perantau Asal Bangka yang Tinggal di Bandung. Psympathic: Jurnal IImiah Psikologi, 5(2), 645-654.

18. Tarabulsy, G. M., \& Symons, D. K. (2016). Attachment Theory and Developmental Psychology: Canadian Contributions and Introduction to The Special Issues. Canadian Journal of Behavioral Science/Revue Canadienne des Sciences du Comportement, 48 (1), 1-8.

19. Zulnisa Riza. (2016). Pengaruh antara kelekatan orangtua and teman sebaya terhadap kesepian pada remaja dengan kecenderungan problematic internet use. Sarjana thesis, Universitas Negeri Jakarta. 